\title{
Sources of light-absorbing aerosol in arctic snow and their seasonal variation
}

\author{
Dean A. Hegg ${ }^{1}$, Stephen G. Warren ${ }^{1}$, Thomas C. Grenfell ${ }^{1}$, Sarah J Doherty ${ }^{2}$, and Antony D. Clarke ${ }^{3}$ \\ ${ }^{1}$ Department of Atmospheric Sciences, University of Washington, Seattle, WA, USA \\ ${ }^{2}$ JISAO, University of Washington, Seattle, WA, USA \\ ${ }^{3}$ School of Ocean and Earth Sciences and Technology, University of Hawaii, Honolulu, Hawaii, USA
}

Received: 25 May 2010 - Published in Atmos. Chem. Phys. Discuss.: 4 June 2010

Revised: 2 November 2010 - Accepted: 13 November 2010 - Published: 22 November 2010

\begin{abstract}
Two data sets consisting of measurements of light absorbing aerosols (LAA) in arctic snow together with suites of other corresponding chemical constituents are presented; the first from Siberia, Greenland and near the North Pole obtained in 2008, and the second from the Canadian arctic obtained in 2009. A preliminary differentiation of the LAA into black carbon (BC) and non-BC LAA is done. Source attribution of the light absorbing aerosols was done using a positive matrix factorization (PMF) model. Four sources were found for each data set (crop and grass burning, boreal biomass burning, pollution and marine). For both data sets, the crops and grass biomass burning was the main source of both LAA species, suggesting the non-BC LAA was brown carbon. Depth profiles at most of the sites allowed assessment of the seasonal variation in the source strengths. The biomass burning sources dominated in the spring but pollution played a more significant (though rarely dominant) role in the fall, winter and, for Greenland, summer. The PMF analysis is consistent with trajectory analysis and satellite fire maps.
\end{abstract}

\section{Introduction}

A number of recent studies have suggested that light absorbing aerosols (LAA), broadly assumed to be largely black carbon (BC), deposited to the snow pack are an important contributor to the warming of the Arctic (Hansen and Nazarenko, 2004; Flanner et al., 2007; McConnell et al., 2007; Shindell and Faluvegi, 2009). An important facet of this issue, partic-

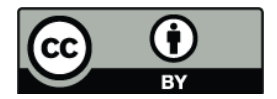

Correspondence to: D. A. Hegg (deanhegg@atmos.washington.edu) ularly from the standpoint of possible remediation, is quantitatively understanding the sources of the LAA in the snow.

Until recently, direct measurements of black carbon in arctic snow have been geographically sparse (e.g., Clarke and Noone, 1985; Chylek et al., 1992; Masclet et al., 2000; Grenfell et al., 2002; Hagler et al., 2007; Perovich et al., 2009). As a consequence, source attribution of snow BC has relied primarily upon numerical transport modeling coupled with validation comparisons with these limited data (e.g., Generoso et al., 2007). However, in 2007 a study was initiated under the auspices of the NSF Arctic Program to rectify the lack of data on black carbon in arctic snow and, in particular, the poor geographic coverage of large portions of the arctic (Doherty et al., 2010). During the second year of this program, snow samples were acquired at numerous sites around the arctic basin, including a substantial number in Siberia, a region hitherto completely devoid of data. That data set was then used in a receptor modeling analysis to determine the LAA sources (Hegg et al., 2009). The dominant source of LAA for three of the four arctic regions examined (Greenland, Russia and Canada) was biomass burning. The fourth region, the area near the North Pole, whose main source of LAA was industrial pollution, was the only exception. We found this result surprising. While the importance of biomass burning has been recognized, at least on an episodic basis (cf., Stohl et al., 2006; Warneke et al., 2009), most general analyses, largely based on numerical models, have suggested that the main source of LAA in the arctic is commonly (though not always) fossil fuel combustion (e.g., Flanner et al., 2007; Ramanathan and Carmichael, 2008). One noteworthy exception to this is the recent ice core analysis of McConnnell et al. (2007), which suggests that since $\sim 1950$ the main source of LAA (measured as BC) in the Greenland snow has been biomass burning. This finding is

Published by Copernicus Publications on behalf of the European Geosciences Union. 
Table 1. Shown are the median and standard deviation of estimated $\mathrm{BC}\left(C_{\mathrm{BC}}^{\mathrm{EST}}\right.$ of Doherty et al., 2010), the absorption Ångstrom exponent and the fraction of non-BC light absorption, spectrally integrated from 300-750 nm and at 650-700 nm. Data are for surface samples only (N. Pole, Russia, Canada and Greenland spring) or of new snow (Greenland summer).

\begin{tabular}{|c|c|c|c|c|c|}
\hline Region & Number of samples & Estimated BC (ppbm) & $\begin{array}{l}\text { Absorption Ångstrom } \\
\text { exponent }\end{array}$ & $\begin{array}{l}\text { Percent Non-BC absorption } \\
\text { (spectral average, } 300-750 \mathrm{~nm})\end{array}$ & $\begin{array}{l}\text { Percent Non-BC absorption } \\
(650-700 \mathrm{~nm})\end{array}$ \\
\hline N. Pole area, 2008 & 4 & $5 \pm 2$ & $2.4 \pm 0.5$ & $46 \pm 13$ & $23 \pm 8$ \\
\hline Greenland, 2008, summer & 37 & $1 \pm 1$ & $1.8 \pm 0.4$ & $31 \pm 10$ & $16 \pm 5$ \\
\hline Greenland, 2008, spring & 7 & $4 \pm 2$ & $2.7 \pm 0.2$ & $55 \pm 8$ & $28 \pm 7$ \\
\hline Eastern Siberia, 2008 & 14 & $21 \pm 30$ & $2.2 \pm 0.3$ & $43 \pm 7$ & $22 \pm 5$ \\
\hline Canadian Arctic, 2009 & 256 & $8 \pm 3$ & $2.2 \pm 0.2$ & $43 \pm 7$ & $21 \pm 7$ \\
\hline
\end{tabular}

in agreement with the analysis of Hegg et al. (2009), but the latter expands the coverage to the arctic as a whole, at least for the 2006-2007 snow season.

Given the importance of such a shift in our understanding of the source attribution of LAA in arctic snow, more receptor modeling for other time periods to corroborate the results to date is essential. Furthermore, other related issues need to be addressed. For example, biomass burning emissions in the Northern Hemisphere have a strong seasonality, the burning season generally being in late spring and summer (e.g., Generoso et al., 2007; Warneke et al., 2009: Stohl, 2006). A perusal of remote retrieval data from the MODIS Fire Mapper (http://rapidfire.sci.gsfc.nasa.gov/firemaps) further suggests a spring maximum, at least during the last five years. Recently, there have been suggestions that the fire season is commencing earlier in the spring due to an earlier onset of snow melt (cf. Stohl et al., 2006), but the season for burning would expand by at most a month and thus still be in spring. Industrial emissions of aerosols, on the other hand, tend to be more invariant seasonally. Additionally, transport into the arctic from mid-latitudes is favored during the spring (e.g., Stohl, 2006), further enhancing the impact of spring burning. As a consequence of this, biomassburning aerosols tend to show concentration maxima during the spring and summer at arctic receptor sites (e.g., Quinn et al., 2007). Hence, one might expect the impact of biomass burning sources of LAA to be most important in the topmost portion of the snow pack in the spring, just before melting commences. In fact, this is where the concentration of LAA is often (but not always) highest and also where the impact of LAA on the snow albedo is greatest (Clarke and Noone, 1985; Flanner et al., 2007; Grenfell et al., 2002). Assessment of seasonal variability in the source strengths of the LAA in more than one year would add much to the credibility of this model of the seasonal evolution of LAA in arctic snow.

Another issue of great recent interest is the precise nature of the light-absorbing aerosol (LAA) in the snow, which includes not only black carbon but also "brown carbon" (i.e., light-absorbing organics) and mineral dust. Spectrophotometric analysis of LAA in snow not only provides information on snow BC concentrations but also gives the spectral absorption of all LAA captured on the snow filters (Grenfell et al., 2010). This information has been used in a preliminary assessment of the partitioning of the light absorption in the snow between $\mathrm{BC}$ and non-BC aerosol. A summary of the findings is presented in Table 1, taken from Doherty et al. (2010). Light absorption by non-BC aerosol varies substantially both temporally and spatially but is typically $\sim 20 \%$ of the total aerosol light absorption at 650-700 nm (last column of Table 1). If one weights the absorption by the solar spectrum over the range of interest for snow $(300-750 \mathrm{~nm}$; Doherty et al., 2010), then the non-BC absorption fraction is even larger due to the enhanced absorption at shorter wavelengths (column 4 of Table 1). For all arctic data analyzed, the spectrally weighted fraction of absorption due to non-BC has a median of $41 \%$ with 95 percent of the data falling between 20 and 70\% (Doherty et al., 2010). It is therefore of interest to determine whether or not the non-BC LAA has the same sources as the black carbon and, if not, what are these sources.

Finally, in Hegg et al. (2009), two distinct biomass source profiles were identified, with one more prevalent in the Russian arctic and the other in the Canadian arctic. We speculated then that one might be a marker for agricultural burning and the other for boreal fires. We pursue this issue further here since, if biomass burning is in fact the main source of snow LAA, refinement of this source with respect to fuel type and location would contribute substantially to the refinement of prognostic models and possible remediation strategies.

\section{Methodology}

\subsection{Chemical speciation}

The laboratory analysis of both the water and filter samples in general followed the procedures described by Hegg et al. (2009). Briefly, the water samples, derived from filtering melted snow through Nuclepore filters in the field, are treated with biocide, and then refrozen. After arrival in the laboratory, they are melted and subjected to analysis by ion chromatography (IC), liquid chromatography, and inductivelycoupled plasma-optical emission spectroscopy as per Hegg et al. (2009). In a few instances, unfiltered snow samples 
corresponding to the filtered samples were also analyzed to assess the possible impact of filtering on the soluble analytes. No significant difference between filtered and unfiltered samples was observed. The filters themselves were analyzed optically for absorption as per Grenfell et al. (2010). However, after the optical measurements, the treatment of the filters deviated from our previous approach. Rather than extraction in hexane for PAH analysis - which has proved to be of limited value in source attribution - the filters were extracted in $750 \mathrm{mM} \mathrm{NaOH}$ and then run through a macroporous vinylbenzyl chloride/divinyl benzene IC column, the substrate fully functionalized by alkyl quaternary ammonium groups (Dionex Inc., MA 1 Carbopac column), coupled to a pulsed amperometric detector (IC-PAD) for analysis of vanillin (4 methoxy, 3 hydroxy benzaldehyde). This technique is fairly sensitive and, used in conjunction with concentration during filter extraction, yields a detection limit for vanillin in snow of $\sim 50$ ppt. This led to detection of the analyte in $94 \%$ of the samples.

Vanillic acid is a well-known biomass-burning marker, recently used, for example, by McConnell et al. (2007) to identify biomass burning as the major source of black carbon in Greenland snow. The closely related vanillin, and various associated methoxy phenols, are equally if not more prevalent products of biomass combustion, specifically lignin combustion (e.g., Simoneit, 2002; Hays et al., 2005; Oros and Simoneit, 2001a; Oros et al., 2006) - and have also been found in Arctic snow in substantial concentrations (Grannas et al., 2004). Vanillin is thus typically preferentially found in burning emissions from boreal biomass as compared to another well-known biomass tracer, levoglucosan, a cellulose combustion product found in emissions from all plant combustion (Simoneit, 2002). For example, the vanillin to levoglucosan ratio in emissions from agricultural biomass burning (typically low in lignins) has been found to be $\sim 10^{-3}$ (e.g., Hays et al., 2005) whereas in boreal conifers it has been found to be 0.1-0.3 (e.g., Oros and Simoneit, 2001a). The absolute magnitude of this ratio for particular fuel loads is likely strongly dependent on the precise analytical techniques employed but it seems clear that agricultural burning emissions should have much lower ratios than boreal biomass burning. In this study we explore the feasibility of using this ratio to discriminate agricultural burning from boreal biomass burning.

Several recent studies have suggested that levoglucosan can significantly degrade during atmospheric transport, at least under some conditions (Hennigan et al., 2010; Hoffmann et al., 2010). However, for our wintertime and high latitude conditions, such degradation should be minimal. Such has been found to be the case in other recent studies for winter conditions (e.g., Mochida et al., 2010).

In addition to the chemical species just discussed, the PMF analysis was run with the concentrations of black carbon (BC) and "non-BC LAA" as given by the photometric analysis. These are derived using a methodology somewhat similar to that described by Sandradewi et al. (2008) to re- solve contributions to particulate matter derived from traffic and biomass burning. Briefly, the spectrally-resolved optical depth of the aerosol on the filter is first measured to get a maximum possible $\mathrm{BC}$ concentration $\left(C_{\mathrm{BC}}^{\mathrm{MAX}}\right.$ in Grenfell et al. 2010) by assuming that all of the absorption in the spectral interval 650-700 $\mathrm{nm}$ is due to BC. Then using the measured light-absorption Ångstrom exponent along with assumed absorption Ångstrom exponents for BC (1.0) and non-BC lightabsorbing aerosol (5.0), the true $\mathrm{BC}$ concentration $\left(C_{\mathrm{BC}}^{\mathrm{EST}}\right.$ in Grenfell et al., 2010, here simply "BC") is estimated. Here, "non-BC LAA" is the difference between the $C_{\mathrm{BC}}^{\mathrm{MAX}}$ and $C_{\mathrm{BC}}^{\mathrm{EST}}$ values of Grenfell et al. (2010). Thus, this concentration equals the true concentration of non-BC LAA only to the extent that (a) our partitioning of BC and non-BC light absorption is accurate and (b) the mass absorption cross-section (MAC) of the non-BC LAA equals that of our BC calibration standards. Regarding the former assumption, the choice of the Angstrom exponent for the BC and non-BC aerosol, the root of the assumption, is based on literature values (e.g., Kirchstetter et al., 2004; Sun et al., 2007) with that for the BC considerably more certain than that for non-BC, as discussed in Doherty et al. (2010). Regarding the latter assumption, the non-BC LAA MAC almost certainly differs from that of our BC standards $\left(6.0 \mathrm{~m}^{2} / \mathrm{g}\right.$ in the spectral interval $650-700 \mathrm{~nm}$ ), but the inferred concentration will be a linear function of the MAC used. Similarly, while more complex, the dependence of the partitioning of LAA between BC and non-BC turns out to be nearly a linear function of the choice of non-BC Ångstrom exponent over the exponent range of $3-6$, subsuming most of the reported values for this parameter. For source attribution we are primarily concerned with how the LAA concentration co-varies with other chemical markers, rather than with its absolute value. Consequently, the linear dependence of the $\mathrm{BC}$ and non-BC concentrations on our assumptions of MAC and non-BC Ångstrom coefficient mean these assumptions have a minor effect on our source attribution analysis. Furthermore, and perhaps more fundamentally, our basic goal is the source attribution of the light absorbed by LAA in our snow samples. Because of the linear dependencies of the inferred BC and non-BC concentrations on this light-absorption, as just discussed, the source attribution of the light absorption is completely independent of our assumptions, the "mass concentrations" acting merely as surrogates in the input data matrices. However, because of uncertainties in the MAC of both BC and BrC LAA, and their possible variation from sample to sample, it must always be kept in mind that the $\mathrm{BC}$ and $\mathrm{BrC}$ mass concentrations reported in the following analysis are simply the concentrations of the calibration aerosol that would give light absorption equivalent to that observed. 
In addition to the input data matrices, associated error or uncertainty matrices are necessary for the PMF model. The equation-based approach to construction of these uncertainty files was used (Norris et al., 2008). Uncertainty estimates and detection limits for each species were based on analysis of replicate standards with uncertainties calculated as twice the standard error of the mean for each analyte species.

\subsection{Data base}

Two distinct data sets have been used for this analysis. The first of these was acquired in 2008, with samples obtained at or near four sites in eastern Siberia, at the Dye-2 site in southern Greenland and an area near the North Pole. The collection period in Siberia and the Arctic Ocean was from 1 April to 8 May but was late July in Greenland. At the four main Siberian sites and Greenland, snow samples were obtained not just near the surface but also throughout the snow column, thus permitting assessment of source strengths over the entire snow deposition season.

The second data set used here was obtained in 2009 in the Canadian High Arctic. As with the earlier data from Canada used in Hegg et al. (2009), the sampling period was the spring (26 April to 6 May) but the present set has much enhanced geographic coverage, including numerous samples from the High Arctic. Samples were obtained at 24 sites, and at all sites vertical profiles of water samples through the snow pack were obtained. The sample locations for both data sets are shown in Fig. 1.

\subsection{Receptor modeling}

Receptor modeling, a form of multivariate statistics, is a generally accepted technique for source attribution of aerosols when source emission profiles are uncertain or even unknown. Perhaps the most widely used receptor approach is that of Positive Matrix Factorization (PMF) (Paatero and Tapper, 1994), which has been used on several occasions on arctic data sets (e.g. Polissar et al., 1998; Xie et al., 1999). We in fact used a PMF model in our analysis of a 2007 data set on snow composition, deriving the sources of $\mathrm{BC}$ in the snow pack (Hegg et al., 2009), as per the above discussion. In that instance the specific model used was the US EPA PMF model 1.1, which had been widely used in regulatory assessments. For this study, we use the most recent and extensively updated version of this model, US EPA PMF 3.0.

\subsection{Back trajectory cluster analysis}

Back trajectory analysis of various sorts has long been used as a tool for either identifying or confirming sources of atmospheric pollution, and has been so used in the arctic (e.g., Treffeisen et al., 2004; Eleftheriadis et al., 2009). We utilize it here as a consistency check on the results of the PMF analysis. The particular model used is the NOAA HYSPLIT IV model, in a cluster analysis mode (Treffeisen et al., 2004;

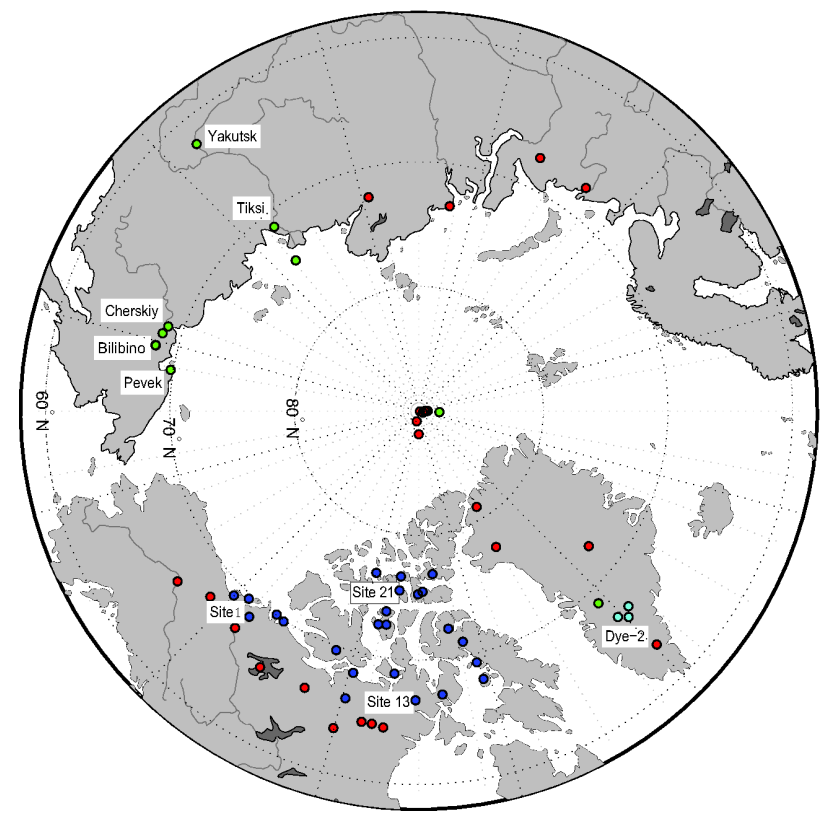

Fig. 1. Sampling sites for the 2008 (green dots) and 2009 data sets (blue dots) analyzed in this study, and for the 2007 data set (red dots) of Hegg et al. (2009).

Toledano et al., 2009). The back trajectories were initialized at an altitude of $500 \mathrm{~m}$ a.g.l. This was selected because it is a typical altitude for the accretion zone of the mixed-phase low level clouds that are characteristic of the arctic spring and fall (e.g., Hobbs and Rangno, 1998; Morrison et al., 2005; Luo et al., 2008). Hence, it is the altitude from which most of the LAA is incorporated into the snow that reaches the ground. However, in sensitivity studies, back trajectories were also run at altitudes of $300,400,700 \mathrm{~m}$. All showed the same general pattern, although the $300 \mathrm{~m}$ trajectories were significantly shorter. A few $1500 \mathrm{~m}$ trajectories were also run and these did show significant divergence from those at lower levels, but this altitude is well above the level where most LAA would be incorporated into hydrometeors.

\section{Results and Discussion}

\subsection{PMF source profiles and their interpretation}

Exercising the PMF model in robust mode on the 2008 data set with various factor numbers yielded an optimal solution (with $\mathrm{Q}_{\text {robust }} \sim 2 \times \mathrm{Q}_{\text {theoretical }}$ ) for four factors or sources. This was true for each of six random seeds. The source profiles for these four sources are shown in Fig. 2a. The validity of the four-factor solution was also tested by inputting essentially the same data (Phosphorous was substituted for nss K due to the large number of zeros in nss K) to the EPA UNMIX model with its NUMFACT algorithm for a more objective determination of the number of sources present (cf., Henry et 


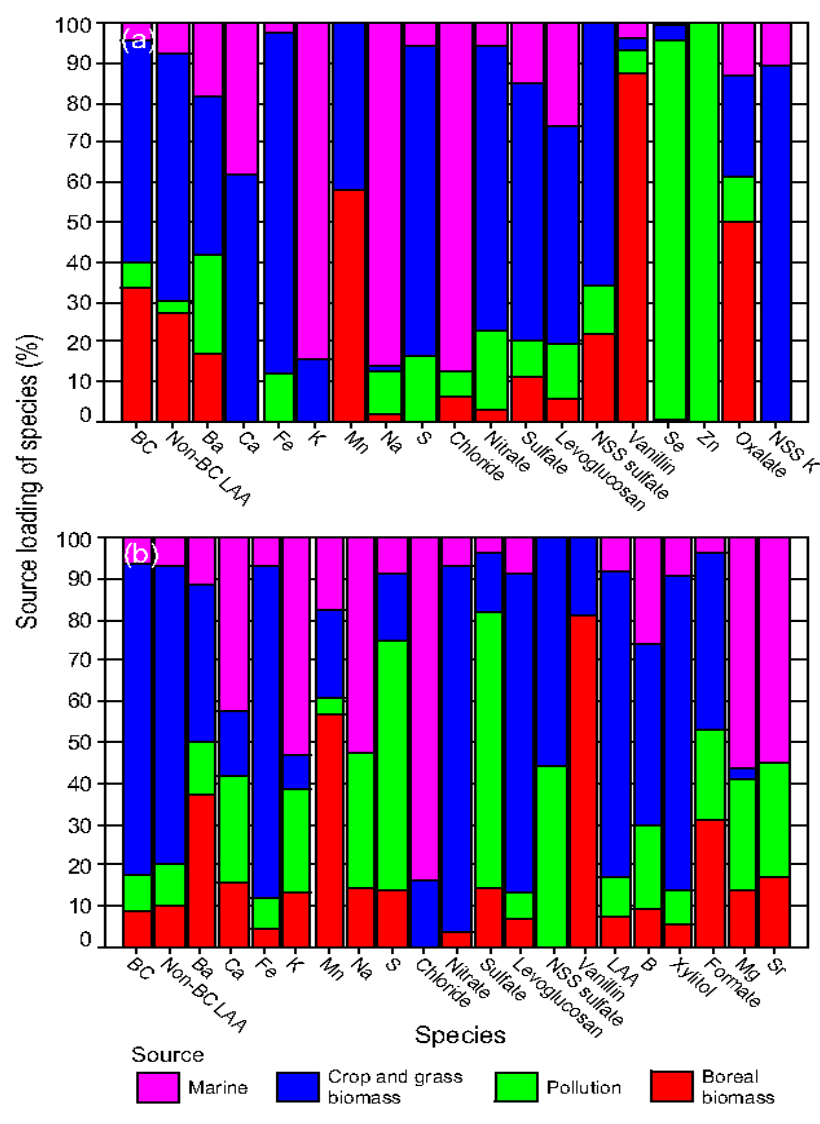

Fig. 2. (a) Source profiles for the 2008 data set. (b) Source profiles for the 2009 (Canadian) data set.

al., 1999). Only a four-factor solution proved possible. The four-factor solution was next tested for rotational ambiguity by varying the FPEAK parameter. A plot of Q vs. FPEAK value is given in the Supplemental Information file (Fig. S1). The minimum in the Q vs. FPEAK plot is rather well defined and the variation in the factor loadings with FPEAK values is generally slight (Fig. S2). Hence, while the proper number of factors into which a particular data set can be resolved can never be categorically asserted (cf., Ulbrich et al., 2009), the four-factor solution found here has substantial support.

Examining Figure 2a, it is evident that both forms of LAA have nearly identical source profiles (a finding echoed in the 2009 data set discussed below). This suggests that their source attribution is essentially the same. While it is conceivable that this congruence is due at least in part to failure of the technique employed to fully resolve the two species, it would also be consistent with the likely nature of the non-BC LAA. The non-BC LAA is differentiated from BC by its increasing light absorption with decreasing wavelength in the visible to near-UV region of the spectrum (Grenfell et al., 2010). This characteristic is associated with "brown carbon" (BrC), essentially light-absorbing organic carbon (Moosmuller et al., 2009), and with mineral dust containing iron oxides. Recent studies have suggested that $\mathrm{BrC}$ is largely derived from various sorts of biomass burning (Lukacs et al., 2007; Favez et al., 2009a; Favez et al., 2009b), which is also a major source of BC in the arctic (e.g., Hegg et al., 2009). Hence, similar sources for $\mathrm{BC}$ and $\mathrm{BrC}$ in this data set is quite plausible, presuming that the factors upon which the $\mathrm{BrC}$ and $\mathrm{BC}$ load are in fact biomass. This leads us to the identification of the sources indicated in the analysis.

A marine source, characterized by high loadings of $\mathrm{Na}$, $\mathrm{Cl}$ and $\mathrm{K}$ is clearly evident. However, as noted in Hegg et al. (2009), it is important to realize that this does not mean that the ocean should be considered a source of LAA. Rather, the LAA associated with this factor had a non-marine source but experienced a trajectory over the open ocean. The percentage of the LAA loaded onto this factor is the lowest of any of the factors. Another factor with an almost equally low loading of LAA is distinguished by very high loadings of $\mathrm{Zn}$ and Se and modest but significant loadings of $\mathrm{Ba}$ and $\mathrm{S}$. The metal species are characteristic of smelter emissions, such as those from the gigantic complex at Noril'sk and the somewhat smaller (but still very large) complex at Sudbury, Ontario (cf., Rahn et al., 1983). The relatively low S loading is a bit unexpected. However, as pointed out by Rahn et al. (1983), while these smelters are the largest point sources of sulfur on the planet, there are many other sources of $\mathrm{S}$ (and sulfate) that, while much lower in intensity, cover much larger areas and simply add up. As a consequence of this, a lower percentage allocation of $\mathrm{S}$ compared to the trace metals (which are more uniquely associated with refining processes) would be expected. Conversely, we note that one of the remaining two sources resolved, crop and grass biomass, (see discussion below), has by far the highest loading of NonSea-Salt (NSS) sulfate, normally considered a predominantly industrial product (via oxidation of $\mathrm{SO}_{2}$ ). Biomass burning does in fact yield NSS sulfate emissions (Hegg et al., 2009) but in large part we feel that this loading arises from the huge geographic extent of biomass burning in Siberia, affording the opportunity for the burning emissions to mix with various industrial sources to augment the sulfate actually emitted in the fires.

The last two sources shown in Fig. 2, and the two most heavily loaded by LAA (both BC and non-BC), are characterized by very high loadings of vanillin and levoglucosan, respectively. The two loadings are, however, largely orthogonal., though the vanillin factor also has some levoglucosan and vice versa. Since levoglucosan is the product of essentially any sort of plant combustion, one would expect it to be present in any biomass burning (Simoneit, 2002). Vanillin is also a well-known marker for biomass burning (Simoneit, 2002; Oros and Simoneit, 2001a; Hays et al., 2005). Additionally, both NSS potassium, loaded strongly onto one of the sources, and oxalate, loaded strongly onto the other, are well-known biomass burning emissions (Hegg et al., 2009). Hence, we interpret both of these last two sources as biomass burning, though the different character of the loadings shown 
in Fig. 2a suggest that the biomass burning sources they represent are distinct. Most tellingly, while levoglucosan, an anhydrous sugar, is the product of cellulose combustion and thus found in virtually all plant burning emissions, vanillin, a methoxy phenol, is the product of combustion of lignin and is found preferentially in the combustion of trees, either conifers or (even more markedly) deciduous (Oros and Simoneit, 2001a; 2001b). In contrast, vanillin emissions from crop or grass burning is slight (Hays et al., 2005; Oros et al., 2006). While observed ratios of vanillin to levoglucosan in fire emissions vary widely, they tend to be orders of magnitude higher in emissions from boreal biomass burning, which are mostly fueled by conifers and deciduous trees, than from agricultural or grass burning (as per the above references). From the above references, the ratio of vanillin to levoglucosan from boreal burning is typically $\sim 50$ times that for crop and grass burning and can be as much as 266 times higher (for combustion of pine as compared to wheat grass). For the 2008 data set, the "vanillin" source has a ratio of vanillin to levoglucosan concentration loading of 80 whereas the "levoglucosan" source has a ratio of 0.5 , i.e., the ratio is $\sim 160$ times higher in the one factor than the other. Consequently, we consider the "vanillin" source to be boreal biomass burning and will henceforth refer to it as such. Similarly, we will call the "levoglucosan" source crop and grass burning. Consistent with this characterization, we further note that the ratio of LAA to potassium in the boreal burning source profile (ratio of 8 ) is much higher than the same ratio in the crop and grass burning source (ratio of 2.2), as per Hegg et al. (2009). Also, it is of interest to note that nitrate, commonly associated with biomass burning as well as pollution, is mostly loaded on the crop and grass burning source and largely absent from the boreal burning profile. We speculate that this is due to the use of fertilizers as well as different $\mathrm{N}$ fixation in the two different biomes. Finally, given this identification of sources, it is important to note that the factors upon which the BC and non-BC LAA are loaded are in fact biomass sources, consistent with the interpretation of the non-BC LAA as BrC. While the non-BC LAA might also be mineral dust, this would require that the dust concentrations co-vary strongly with biomass burning aerosol, a less plausible explanation than the interpretation of non-BC LAA as $\mathrm{BrC}$ (see discussion below).

The PMF model also found four sources as the optimal solution for the Canadian (2009) data set (with $\left.Q_{\text {robust }} \sim 1.4 \times \mathrm{Q}_{\text {theoretical }}\right)$. As with the 2008 data set, 6 random seeds yielded the same four factor solution, which was also confirmed by running the UNMIX model on the same data set. FPEAK sensitivity tests once again suggest little rotational ambiguity and the factor loadings for various FPEAK values changed little (see Fig. S3). The four source profiles are shown in Fig. 2 b. Note that 15 of the analytes are the same as in Fig. 2a; the rightmost analytes listed in the figure are different. As with the 2008 data set, a factor/source that is clearly marine, with high loadings of $\mathrm{Na}, \mathrm{Cl}, \mathrm{K}$ and
$\mathrm{Mg}$ is present. Also present is a "pollution" factor, as was the case in the 2008 data set. However, its component loading is somewhat different, now characterized by high loadings of sulfur species as is normally expected for industrial pollution. On the other hand, while both $\mathrm{Zn}$ and Se, the major loadings on the 2008 pollution source, were not included in the analysis presented in Fig. 2b, sensitivity tests for other analyte suites are revealing. In the case of $\mathrm{Zn}$, exclusion was due to far too many of the samples having concentration below the detection limit and nothing more could be done. For $\mathrm{Se}$, the exclusion was simply due to the fact that the overall variance reduction of the PMF model was degraded when Se was included in the analysis. Hence, with a slight penalty in variance reduction ( $\mathrm{Q}$ increases by $4 \%$ ), the model was re-run with Se included, and $70 \%$ of the Se was found to be loaded on the pollution factor, a result in accord with the composition of the 2008 pollution factor.

As was the case for the 2008 data set, the remaining two sources from the PMF analysis, loaded heavily by either levoglucosan or vanillin, are clearly biomass burning sources. And, again as was the case with the 2008 data, the vanillin to levoglucosan ratio is quite different in the two source profiles, the two species being even more orthogonal than was the case with the 2008 data. We shall label these sources as we did the 2008 biomass factors, the high vanillin factor being indicative of boreal biomass while the levoglucosan factor is associated with crop and grass burning. As before, we note that nitrate is primarily associated with the crop and grass burning source. Also as in the 2008 data set, most of the LAA is associated with biomass burning. However, there is a noteworthy difference: whereas in 2008 boreal biomass burning contributed appreciably to the LAA, in the 2009 Canadian data set over $80 \%$ of the LAA is associated with crop and grass burning alone, the residual roughly equally distributed among the other factors. Finally, it is important to note that again there is no difference between the source allocation of LAA in general and $\mathrm{BC}$, re-enforcing the interpretation of the non-BC LAA as BrC. However, one complicating factor should be considered, at least briefly. Fe is also strongly loaded onto the crop and grass burning source profile in both the 2008 and 2009 data sets. Conceivably this is associated with light- absorbing iron oxides in mineral dust, and part of the non-BC absorption could be due to this since such oxides have a similar spectral absorption signature to that of $\mathrm{BrC}$. (Note that soil dust, i.e., dirt, might well have appreciable absorption and be mixed to some extent with biomass burning but this absorption is due to humic substances, i.e., $\mathrm{BrC}$, and it is unlikely that there would be sufficient saltation of such dirt to have this source rival that of actual combustion aerosol in any case.) Two considerations render this implausible. First, it is unlikely that mineral dust would be so highly correlated with biomass burning that it could not be resolved from this source if it were present in any strength. Its sources are geographically distinct from biomass burning (Chen et al., 2009) and little Fe-containing 
dust (as distinct from dust in general) deposits in our receptor areas (Mahowald et al., 2009). Second, the quantity of Fe present is much too small to account for the non-BC component of the absorption. Using the procedure of Alfaro et al. (2004), and making the very liberal assumption that all of the $\mathrm{Fe}$ is in the form of hematite (the most strongly absorbing Fe form), the average absorption of the Fe would be less than $3 \%$ of that due to $\mathrm{BC}$ for the 2009 data set and $\sim 0.2 \%$ for the 2008 data set. We conclude that the observed non-BC absorption cannot be attributed to Fe.

Though the non-BC absorption is most plausibly due to $\mathrm{BrC}$, because the sources of the two LAA species are essentially identical and their resolution not well-established, we shall henceforth discuss the PMF results only in terms of LAA. Hence, the most noteworthy aspect of the LAA loadings shown in Figs. 2 and 3 is that $\sim 90 \%$ of the LAA in both the 2008 and 2009 data sets is associated with biomass burning.

\subsection{Source contributions to the sampling sites}

\subsubsection{Source contributions in 2008}

With the source profiles in hand, the contribution of each source at each individual sampling site (receptor sites) can be calculated (cf., Hegg et al., 2009). The results of this calculation for the 2008 data set are shown in Fig. 3a. For clarity, rather than displaying individual samples, we have grouped the results for the major sampling regions, i.e., all locations in the general vicinity of the indicated sites are averaged together. It is also important to note that source attributions through the snow profile are averaged together. Thus, what are shown are averages over the entire snow deposition season, rather than for the most recent month or so of snow deposition as was done in Hegg et al. (2009). Note, however, that when the predicted PMF LAA concentrations for individual samples (i.e., the sum of the concentrations from each source) are compared to the actual LAA measurements on a sample by sample basis via linear regression, the $R^{2}$ value for the regression fit is 0.79 for the 2008 data set.

The most prominent characteristic of the source attribution is the site to site variability. For Yakutsk and Tiksi, the most westerly of the Siberian sites (see Fig. 1), the LAA is mostly derived from biomass burning, and more specifically crop and grass burning. At the Cherskiy and Bilibino sites significantly to the east, on the other hand, the main sources of LAA are boreal burning, though the crop and grass burning component is still prominent. At Pevek, where most of the samples were actually taken on sea ice, the main "source" was marine, and at both Greenland and the North Pole, pollution was the predominant source. However, at all three of the latter sites there was still a strong component due to crop and grass burning. The relatively strong pollution signal at the North Pole is similar to that observed in the 2007 data set, suggesting that the previous results were not anomalous
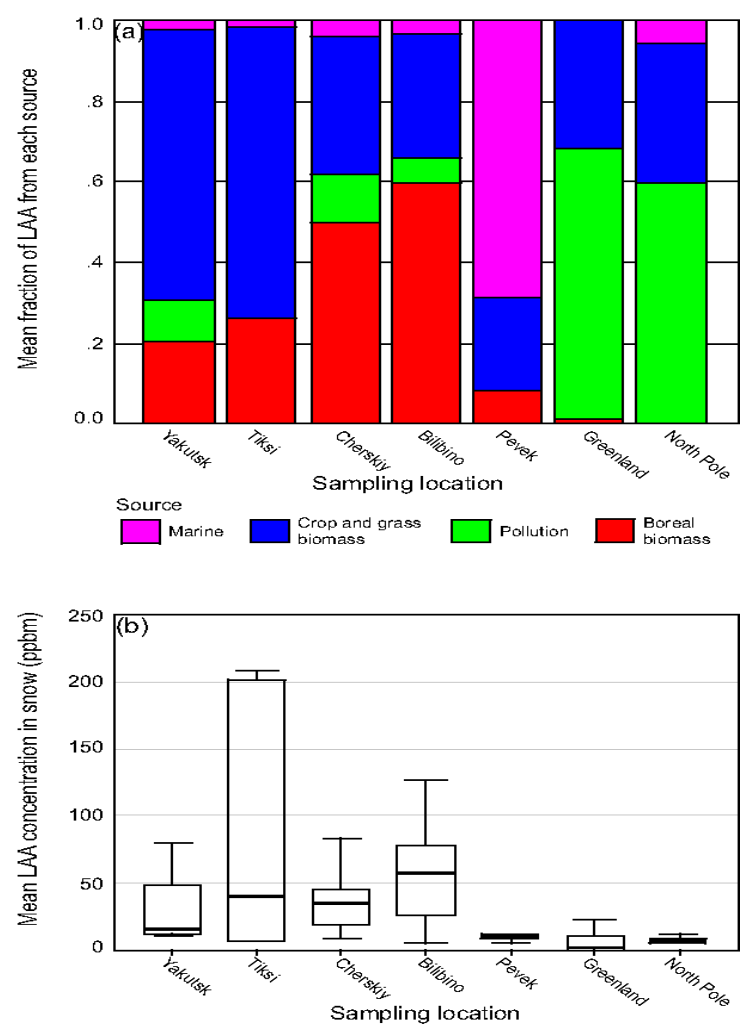

Fig. 3. (a) Average fractional source contributions to the LAA concentration in snow for each of the main sampling locations for the 2008 study. (b) Absolute concentrations of LAA in snow for each of the sites shown in Fig. 3a. The boxes represent the quartile range while the interior lines represent the means. The error bars subsume the $95 \%$ confidence interval.

in terms of the impact of pollution even though the source profiles for pollution differ between the data sets. While the Greenland results do apparently differ from the 2007 study results, more detailed analysis of the time variation of the sources, to be discussed below, resolves the apparent discrepancy, and we defer further discussion until then. For later comparison with the 2009 data set, we note that, averaged over the entire 2008 data set, the source percentage for crops and grass burning is $41 \%$, for boreal burning $25 \%$, for pollution $24 \%$, and $10 \%$ is associated with marine air.

When interpreting the significance of the relative source strengths shown in Fig. 3a, it is important to take into account the differences in the absolute concentrations of LAA at each location. These are shown in Fig. $3 b$ for the 2008 data set. The very low concentrations of LAA in snow at Pevek, Greenland and the North Pole compared to the other sites attenuate the role of pollution as compared to biomass burning as a source of LAA. Conversely, the relatively high mean concentrations at Yakutsk and Tiksi (where crop and grass burning source dominated) as well as at Cherskiy and Bilibino (where the boreal biomass source dominated) suggest 


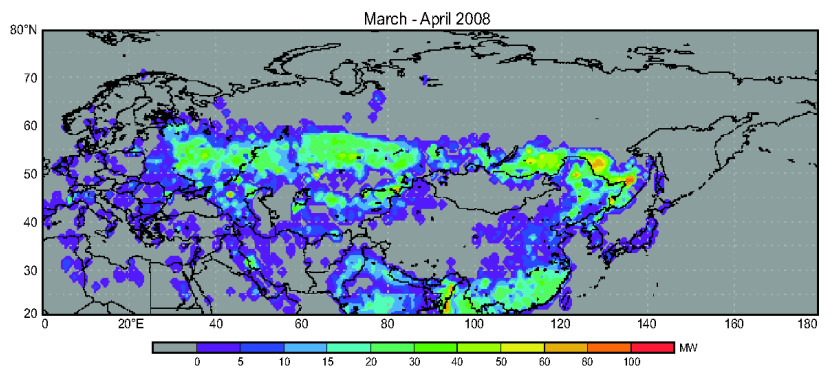

Fig. 4. Location of biomass fires based on the MODIS Fire Mapper (Giovanni program) for March-April of 2008. The resolution of the fire radiative power field (units of MW) is $1^{\circ} \times 1^{\circ}$.

similar, substantial impacts for both boreal and crop and grass biomass burning. The differences in the geographic impact of the two different biomass burning sources are explicable in terms of differential transport and the location of biomass fires during the 2008 fire season.

The location of biomass burning during the 2008 season is shown in Fig. 4. The image is from the NASA Giovanni web site (http://gdata1.sci.gsfc.nasa.gov/daac-bin/G3/ gui.cgi?instance $\_$id=neespi), which is based on Fire Imager data, and is for March-April, a fairly representative period for the east Siberian sampling sites and the peak of the spring fire season. We next utilize the HYSPLIT IV back-trajectory model to qualitatively assess the plausibility of transport of biomass burning products from these fire areas to our receptor sites. Such trajectories (isentropic, 10 day) were calculated every $6 \mathrm{~h}$ for a period from the snow sampling date back sufficiently far to encompass the bulk of the LAA in the snow pack. For this, snow-fall accumulation rates are necessary. Such rates are shown in Fig. 5 for the three east Siberian sites for which we could obtain data. These data were either provided via personal communication from Russian colleagues (S. A. Zimov; V. F. Radionov, personal communication, 2010) or estimated from climatological data scaled by our direct measurements of the total snow depth (Yakutsk). Note that, for the Tiksi site, which is also included in the back trajectory analysis, we assume the snow accumulation rate is the same as those at Cherskiy and Bilibino. Trajectories for Yakutsk are shown in Fig. 6a, for Tiksi in Fig. 6b and for Cherskiy and Bilibino (they are sufficiently close that one analysis suffices) in Fig. 6c. The Yakutsk back trajectories clearly intersect the fire area on numerous occasions to the south, the southeast and well to the west. Since these fires, particularly those to the west-southwest, are largely agricultural., the PMF source contributions, dominated by crop and grass burning, are readily explicable. Similarly, the Tiksi back trajectories (Fig. 6b) have a major component that extends well to the south, roughly following the Ob river valley, and penetrating deeply into the agricultural fire area. In contrast, the back trajectories for Cherskiy and Bilibino (Fig. 6c) are much more localized. There are indeed some that also

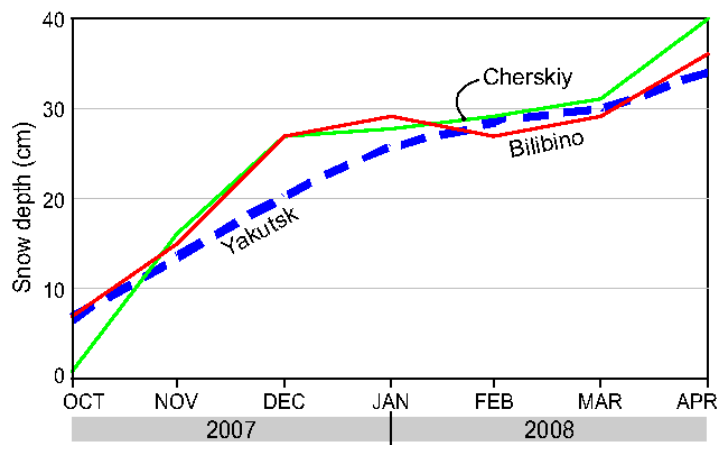

Fig. 5. Snow accumulation as a function of time (monthly averages) for three East Siberian sites used in this study. Note that the Yakutsk depths are estimate based on climatology scaled linearly by the measured total depth. The other site data are direct measurements for the 2007-2008 accumulation season.

penetrate into the agricultural burning areas (as is reflected in an appreciable crop and grass burning source in the PMF profiles) but most are confined to the area north of this region. In early May, images from the Giovanni program do show some fires in this area, which must be largely boreal., but for the period encompassing the observed snow deposition we sampled, no such fires are evident. We suspect that the PMF boreal burning source is due to local burning of fuel wood from boreal trees. Back trajectories for Pevek (not shown) are similarly localized and, to a greater degree than is the case for the other sites, are over the Arctic Ocean. Hence, overall, the back trajectory analysis is consistent with the PMF source attribution for the 2008 data set.

\subsubsection{Source contributions in 2009}

PMF analysis of the 2009 data set from the Canadian arctic yielded the source contributions shown in Fig. 7a. All of the sampling sites are shown for which source contribution estimates could be made ( 21 of 24 sites). The excluded sites had concentration anomalies in key species sufficiently large to render PMF source attribution infeasible. For example, site 4 on the Parry Peninsula was a scant $100 \mathrm{~km}$ from the Smoking Hills, a natural oil shale combustion site with very high sulfur emissions. The consequent very high reduced sulfur concentration at site $4(\sim 70000 \mathrm{ppbm})$ dominated that of all other species and could not be fitted to any of the PMF sources. Geographic labels are provided in Fig. 7 only for those sites that are further discussed on an individual basis. The source contributions are similar to those from the 2008 data set in the sense that biomass burning is the most important contributor to LAA in snow. Indeed, this is true to an even greater extent than for the 2008 data (Siberia, Greenland and the N. Pole), with only a few sites on or near to Little Cornwallis Island showing a significant impact of pollution. However, a divergence is also evident in that crop and grass burning is now the overwhelming biomass source at nearly all stations. 

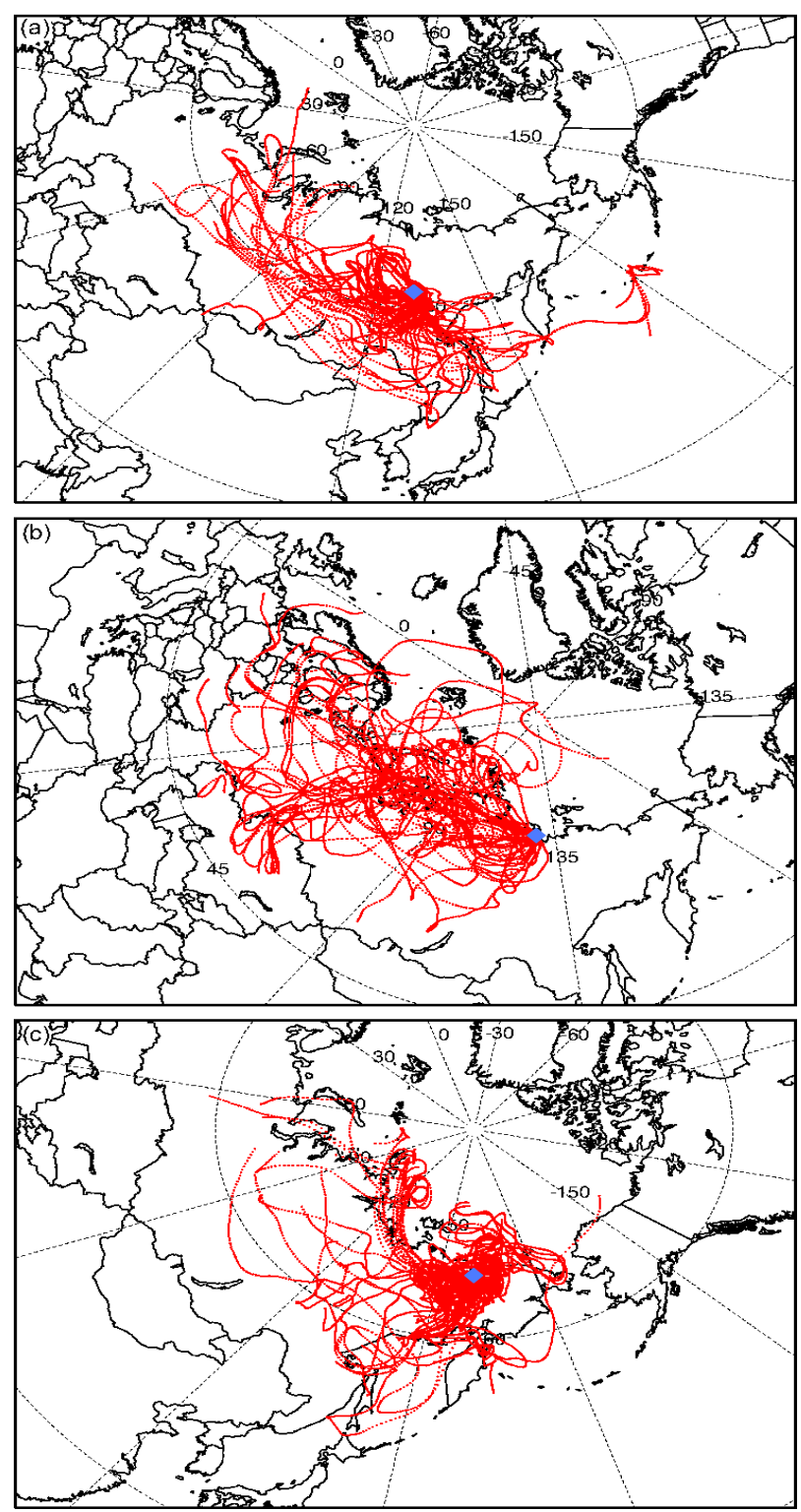

Fig. 6. Isentropic, 10 day back trajectories from HYSPLIT IV initialized at the respective sampling sites for a period $\sim 2$ months prior to the sampling dates for (a) Yakutsk, (b) Tiksi, and (c) Cherskiy. Note that the Cherskiy trajectories are also applicable to nearby Bilibino.

Indeed, averaged over all sampling sites, $75 \%$ of the LAA is attributable to crop and grass burning. Only at the sites near Inuvik (sites 1-3) does boreal burning have any significant impact.

These three are the only sites located within the boreal forest zone. All of the others are located north of the tree line and it is conceivable, as was the case with the Cherskiy and Bilibino sites in Siberia, that the appreciable but still secondarily important boreal biomass source at sites $1-3$ is due to local wood burning for heat.
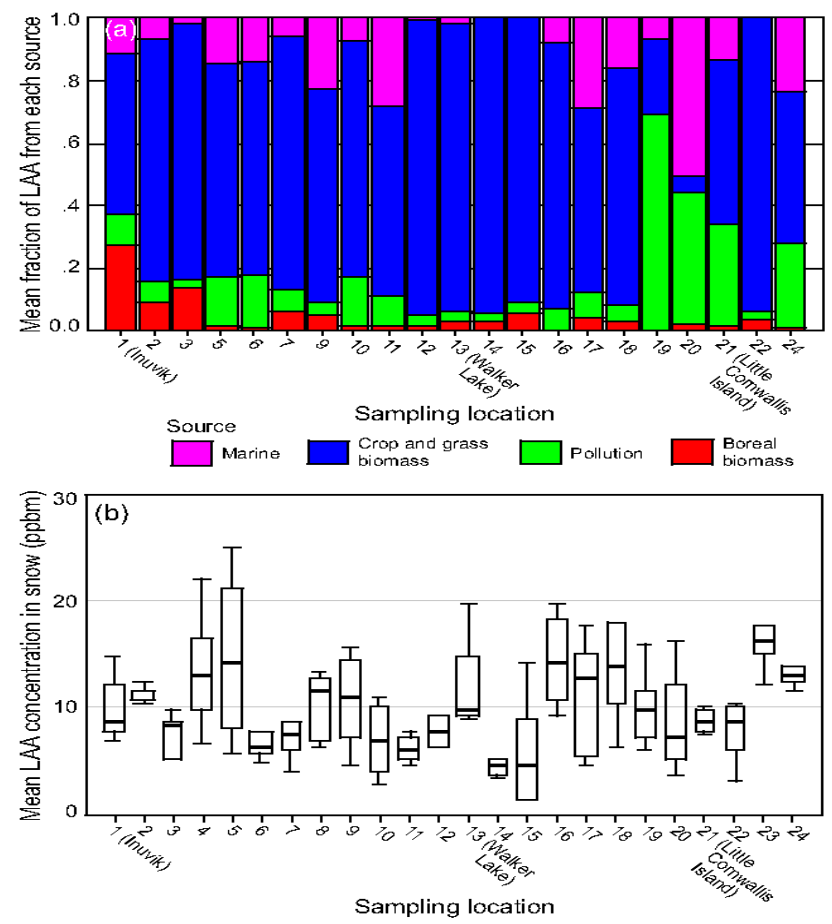

Fig. 7. (a) Average fractional source contributions to the LAA concentration in snow for each of the 24 sampling locations for the 2009 study in arctic Canada. Samples were also averaged over depth. Sampling stations for detailed discussion are labeled with place names. (b) The absolute concentrations of LAA in the snow as per Fig. 3b but now for each of the sites shown in Fig. 7a. (Note the difference in scale compared to Fig. 3b).

The mean LAA concentrations in the snow necessary to complement the source mass fractions in Fig. 7a are shown in Fig. 7b. There is substantial variation between sites, but perhaps the most significant fact is revealed by comparison with the similar plot for the 2008 data set (Fig. 3b), which is dominated by the eastern Siberian sites. It is clear that the Siberian arctic snow has substantially higher LAA levels present than is the case for the Canadian arctic. Once again, we note that comparison of the PMF LAA predicted values for each sample to the corresponding direct measurement via regression yields a high regression $R^{2}$ value, in this case 0.83 .

\subsection{Seasonal variation in sources from depth profiles}

To this point, the discussion has been in terms of depthaveraged profiles to assess the relative magnitudes of the sources over the entire deposition period. The results have supported our earlier finding as to the importance of biomass burning as a source of LAA in arctic snow, based primarily on spring snowpack samples alone (Hegg et al., 2009). We wish to further explore possible seasonality by now turning to analysis of the depth profiles. 


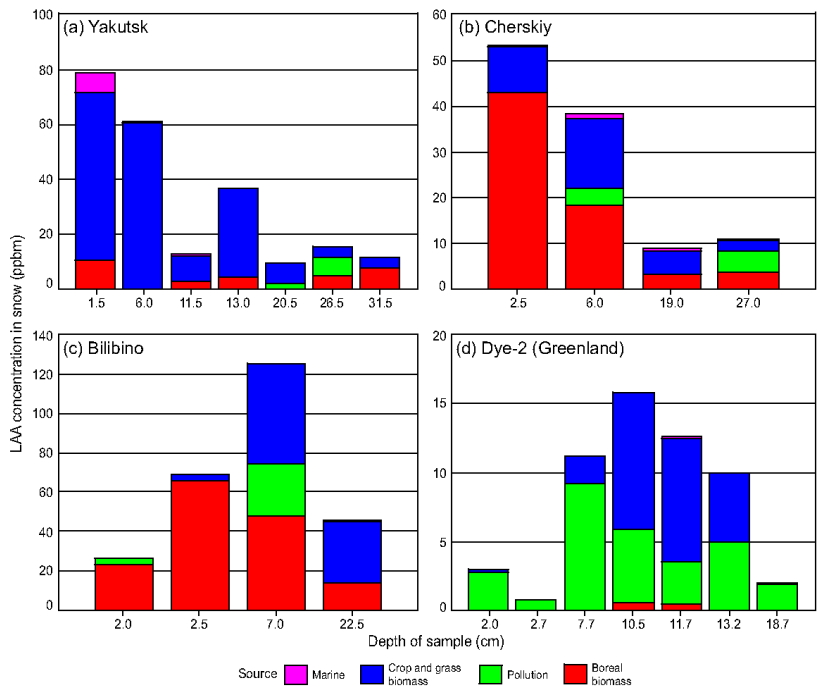

Fig. 8. Depth profile of the source contributions to LAA at sites in the 2008 data set. The source profiles are generated by taking the product of the mass fraction due to each source at each depth and the measured LAA concentration at that depth. (Note that there is a possible bias introduced by this procedure if a substantial portion of the LAA is not assigned to a source by PMF. However, only $\sim 10 \%$ of the LAA is unassigned, based on bootstrapping uncertainty analysis.)

During the 2008 study, vertical profiles of LAA (from filters) were obtained at all Siberian sites but, for logistical reasons, melt water was saved from only a subset of the filter samples. Hence, for the 2008 data set, good depth profiles, though with variable depth resolution ranging from a few $\mathrm{cm}$ to ten's of cm, were obtained only at Yakutsk, Cherskiy, Bilibino and Greenland. At the other locales, while some melt water samples were taken at the surface and some at modest depths up to $\sim 10 \mathrm{~cm}$, no systematic depth profiles were obtained. We therefore concentrate our discussion on profiles from these four locations.

The source profile contributions as a function of sample depth for Yakutsk are shown in Fig. 8a. Note that the LAA concentrations are much higher near the surface, corresponding to roughly the last month of snow fall. This is characteristic of both this data set and the 2007 Siberian data set. This surface maximum is also noteworthy in that the dominant source of the LAA is crop and grass burning, as might be expected from the spring season maximum in such burning. Hence, the surface layer LAA, most important for albedo modulation (Flanner et al., 2007; Grenfell et al., 2002), is largely biomass-burning derived. The other interesting feature of the depth profile is that pollution starts to play a role at $\sim 20-27 \mathrm{~cm}$ depth, corresponding to snow deposition during the previous October-November period (see Fig. 5).
The Cherskiy depth profile, shown in Fig. 8b, also displays a surface maximum in the LAA concentration, once again corresponding to about one month of snow deposition. This peak is also due to biomass burning though in this case it is boreal burning that is the major source. There is also a minor but significant pollution source present in early March and then a more substantial pollution component in November of the previous year, as was the case at Yakutsk. The Bilibino profile, shown in Fig. 8c, differs somewhat from the previous two in that it does not have a surface maximum in LAA. There is a maximum present corresponding to late Februaryearly March deposition, but the depth resolution is poor. On the other hand, in accord with the other profiles, the near surface and thus spring sources are dominated by biomass burning, in this case, as expected, boreal. It is also noteworthy that the pollution source in early March found in the Cherskiy profile is echoed here at $7 \mathrm{~cm}$ depth. Unfortunately, the depth profile does not go sufficiently deep to reveal whether the previous fall pollution source found in the other profiles is also present here.

The final depth profile available in the 2008 data is from Greenland (Fig. 8d). The peak in LAA occurs at a depth of $10.5 \mathrm{~cm}$ and is associated primarily with crop and grass burning, in agreement with both our previous analysis of 2007 data (Hegg et al., 2009) and with the study of McConnell et al. (2007), who found that much of the BC in the Greenland ice cap was derived from biomass burning. Approximate timing of deposition was inferred from the snow depth time series of the Greenland Climate Network (Steffen et al., 1996). While the peak is somewhat deeper than expected given the springtime maximum in biomass burning emissions, this may simply be due to the fact that, unlike the eastern Siberian sampling, sampling at this site was done in late July. Outside of the spring burning interval., the source of LAA in the snow is primarily pollution and, perhaps most tellingly, the surface LAA for this site is largely due to pollution, the snow containing it freshly fallen a few days prior to sampling. For typical snow grain size and LAA loading, the e-folding depth for radiative flux in the visible is on the order of $10 \mathrm{~cm}$. Hence, for this particular site, it is pollution that might be expected to most influence the snow albedo during the summer. However, the interpretation of this profile is more complex than is at first apparent.

Unlike the other sites in this study, the Dye-2 site, in part due to the time of year during which sampling took place, was subject to snow melting (according to reports of the station managers there) and possibly sublimation (e.g., Liston and Sturm, 2004). These post-depositional processes could possibly have altered the depth profiles of the aerosol species in the snow. The most straightforward such alteration would be the accumulation of LAA, assumed to be largely hydrophobic, near the surface as the snow melts and percolates through the underlying snow, presumably also carrying downward any soluble species. Plots of LAA, sulfate and nitrate with depth for the Dye-2 site are shown in Fig. 9 and do 


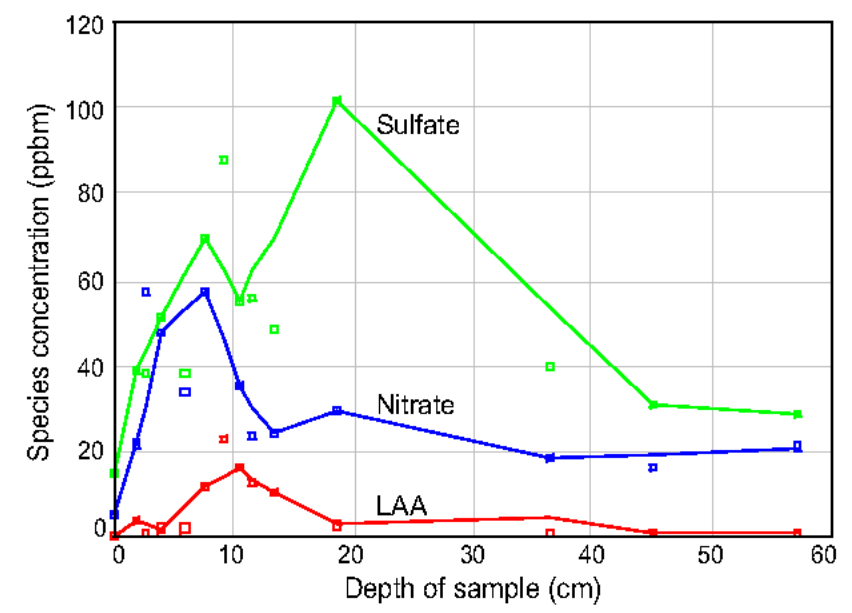

Fig. 9. Depth profiles of selected individual chemical species at the Dye-2 site in Greenland.

hint at such a process. The LAA is indeed concentrated near the surface and the sulfate does show a maximum displaced slightly downward from the LAA maximum. Furthermore, there is a slight secondary nitrate maximum co-incident with the possibly displaced sulfate peak. On the other hand the absolute nitrate maximum is not displaced downward from the LAA peak, there is a strong secondary sulfate peak coincident with the LAA peak, and oxalate (not shown) is also not displaced downward from the LAA peak. In the case of nitrate, it is conceivable that a number of post-depositional processes, including photochemistry, are taking place (e.g., Burkhart et al., 2009) but this is unlikely for oxalate or sulfate. Also, the Dye-2 site is a moderate snow accumulation site $\left(\sim 350 \mathrm{~kg} \mathrm{~m}^{-2} \mathrm{a}^{-1}\right.$ or $\sim 35 \mathrm{~cm} \mathrm{a}^{-1}$ water equivalent) where such post-depositional processes are not well established. Since both sulfate and nitrate are major components of the crop and grass biomass source, what the profiles in Fig. 9 do show is that the association of much of the LAA at this site with crop and grass burning is quite plausible. Nevertheless, the uncertainty associated with this profile is substantially higher than is the case for the others examined in this study.

For the 2009 data set from the Canadian Arctic, the number of profiles available (source depth profiles could be calculated for 19 of the 24 sites) renders discussion of individual profiles unwieldy. Discussion of a mean profile for all of the sites is also not meaningful, due largely to the diverse total depths of the profiles and the non-uniform sampling depths between profiles. Hence, we discuss the entire set of profiles essentially statistically, reserving detailed discussion of individual profiles to a few cases of special interest. First, as implied by the average source contributions for each of the sites shown in Fig. 7a, crop and grass burning dominates the depth profiles, with this source contributing greater than $50 \%$ of the total LAA concentration in $86 \%$ of the samples
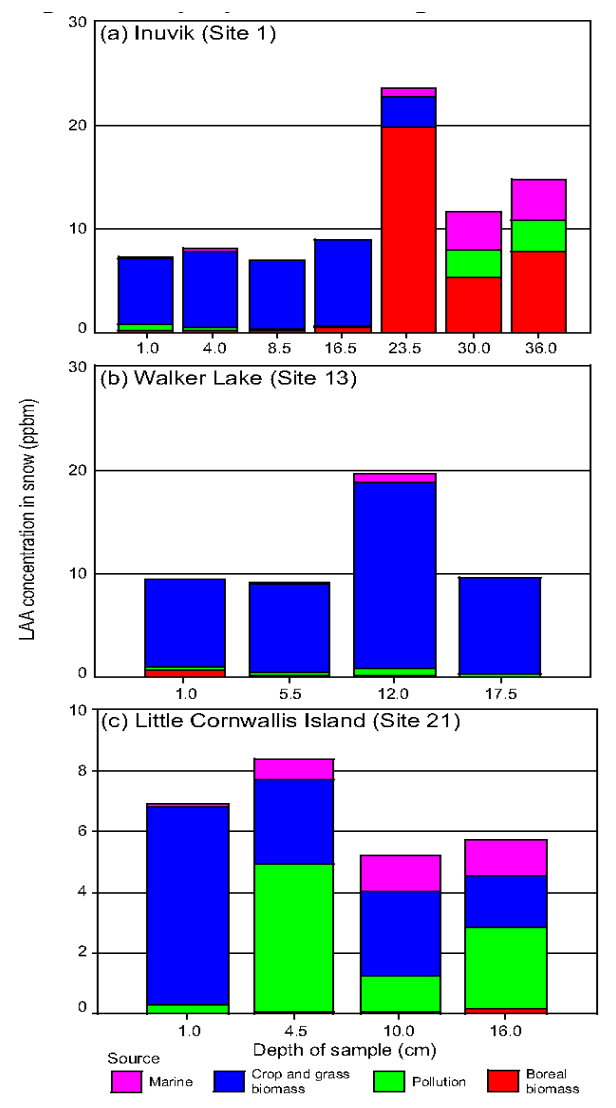

Fig. 10. Depth profiles as in Fig. 8 but now for the 2009 Canadian data set.

inclusive over all depths. Furthermore, in only four instances was the peak LAA concentration in the profile dominated by anything other than crop and grass burning (pollution twice and marine and boreal burning one each).

As was the case for the 2008 data set, the maximum impact of the sources varied with depth. If one looks at the depth at which the maximum fractional contribution to LAA occurred, it varied appreciably with source type. For crop and grass burning, the median depth of maximum impact was $4 \mathrm{~cm}$ (note that we use medians rather than means due to the large influence of a few outlying values at locations with unusually deep profiles). For pollution the median was 8 , for marine it was 12 and for boreal burning $19 \mathrm{~cm}$. Hence, not only was the crop and grass burning source the dominant source of LAA, the LAA from this source was relatively favorably located in the snow pack for radiative impact. As in the 2008 data set, the pollution source (though less important than in the 2008 data) was of more importance earlier in the year than the dominant biomass-burning source.

A few of the sites in the 2009 data set had PMF source contributions that differed significantly from the broad average picture just presented and can profitably be examined further. For example, sites 1-3 near Inuvik were the only 


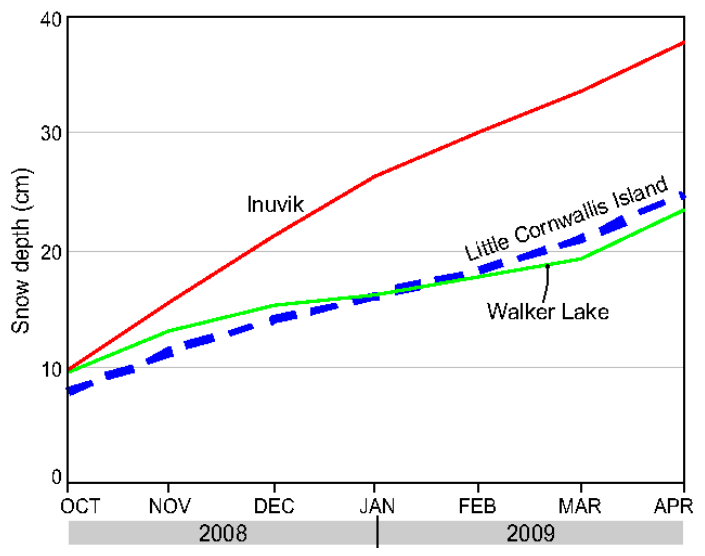

Fig. 11. Snow depths as a function of time (monthly averages) for three sampling locations in the Canadian arctic (2009 data set). The data shown are WMO climatological data. For the Inuvik and Walker Lake sites, these data are in good agreement with the measured snow accumulation at the time of sampling. For the Cornwallis Is site, however, there was a substantial discrepancy and the depths were scaled uniformly (upward) to yield the measured total accumulation at the time of sampling.

locations to display a prominent boreal biomass source signature. Similarly, the sites on or near Little Cornwallis Island. had a strong pollution component to the LAA, and we have selected a profile from one of these sites (site 21) for discussion. For comparison, we also discuss a more typical profile from Walker Lake (site $13,67^{\circ} \mathrm{N}, 91^{\circ} \mathrm{W}$ ).

The depth profile for the Inuvik site is shown in Fig. 10a. A clear differentiation in the source character is seen with depth, the LAA from the top $16 \mathrm{~cm}$ being almost solely due to crop and grass burning whereas at $23.5 \mathrm{~cm}$ and below, boreal burning is the most important source, but with pollution and marine sources also contributing significantly. Presumably this marked difference in sources is due to differences in either transport or relative source strengths, or both. To assess this, we must first translate the depths shown in Fig. 10a to dates. For this, snow depths as a function of time are necessary and are shown in Fig. 11 for the three sampling locations that will be discussed. From the plots, it is clear that the transition in source impact at $\sim 20 \mathrm{~cm}$ depth at Inuvik corresponds to $\sim$ November 2008 . MODIS Fire Imager data from the Giovanni website show fires during October and November that are likely boreal in nature. This is particularly true for western North America but also even for eastern Eurasia, a likely source of biomass burning aerosol over the Canadian arctic (Warneke et al., 2009). On the other hand, fires during the spring of 2009, the major deposition period for the more recent snow at Inuvik, are mostly crop and grass biomass burning in Eurasia, and in North America as well. The seasonal change can be seen by comparing Fig. 4, which gives the geographic distribution of Eurasian fires in the spring with Fig. 12, which gives the fires for the

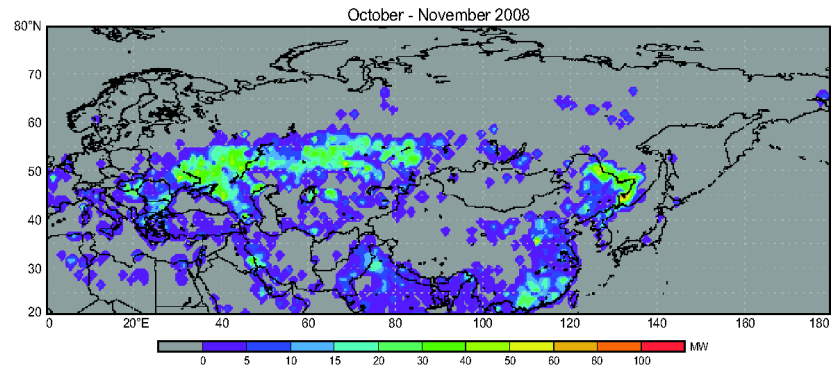

Fig. 12. Location of biomass fires in Eurasia based on the MODIS Fire Mapper (Giovanni program) for October-November of 2008. The resolution of the fire radiative power field is $1^{\circ} \times 1^{\circ}$.

fall of 2008, the period during which the boreal source is strong in the Inuvik depth profile. Fires in the fall are present appreciably to the north of those in the spring period, and are situated in boreal forest rather than crop lands.

The issue of differential transport between the two periods is more difficult to address. Several studies have suggested that major sources of aerosols, and particularly BC, observed over the Canadian arctic and Alaska in the spring are in Eurasia (Sharma et al., 2006; Warneke et al., 2009). The long transport distance this implies necessitates quite long back trajectories, but in the Arctic such long trajectories can be somewhat problematic (cf. Hegg et al., 2009). We have used 10-day back trajectories in this study, a compromise between uncertainty in precision and necessity of length. Such back trajectories from Inuvik for the autumn period of 2008 are shown in Fig. 13a. A small but significant number of the trajectories do in fact reach the boreal fire area shown in Fig. 12. For comparison, back trajectories from Inuvik in the spring of 2009 are shown in Fig. 13b. While most of the trajectories shown are confined to the Canadian arctic itself, some do in fact reach the spring biomass burning areas of Eurasia, which are largely crop and grass burning. Quite possibly, with longer back trajectories more would have done so. Additionally, a number of the trajectories reach nearly to the Canadian-US border, particularly above the mid-west of the US This region also had significant crop biomass burning during the spring period (not shown). Hence, overall, the PMF source changes shown in the depth profile for Inuvik are consistent with differences in source strengths and differential transport over the deposition period.

In contrast to the Inuvik site, the depth profile for Walker Lake (site 13) is uniformly dominated by crop and grass burning (Fig. 10b). This is more typical of the 2009 profiles from across the Canadian Arctic and can be used as a bench mark against which the Inuvik site and the Cornwallis site (discussed below) can be assessed. The only distinct feature in the profile is the maximum at a depth of $12 \mathrm{~cm}$. Given the light snowfall at this site (see Fig. 11), this corresponds roughly to deposition during the autumn of the previous year. During this period, the MODIS/ Giovanni program shows a 

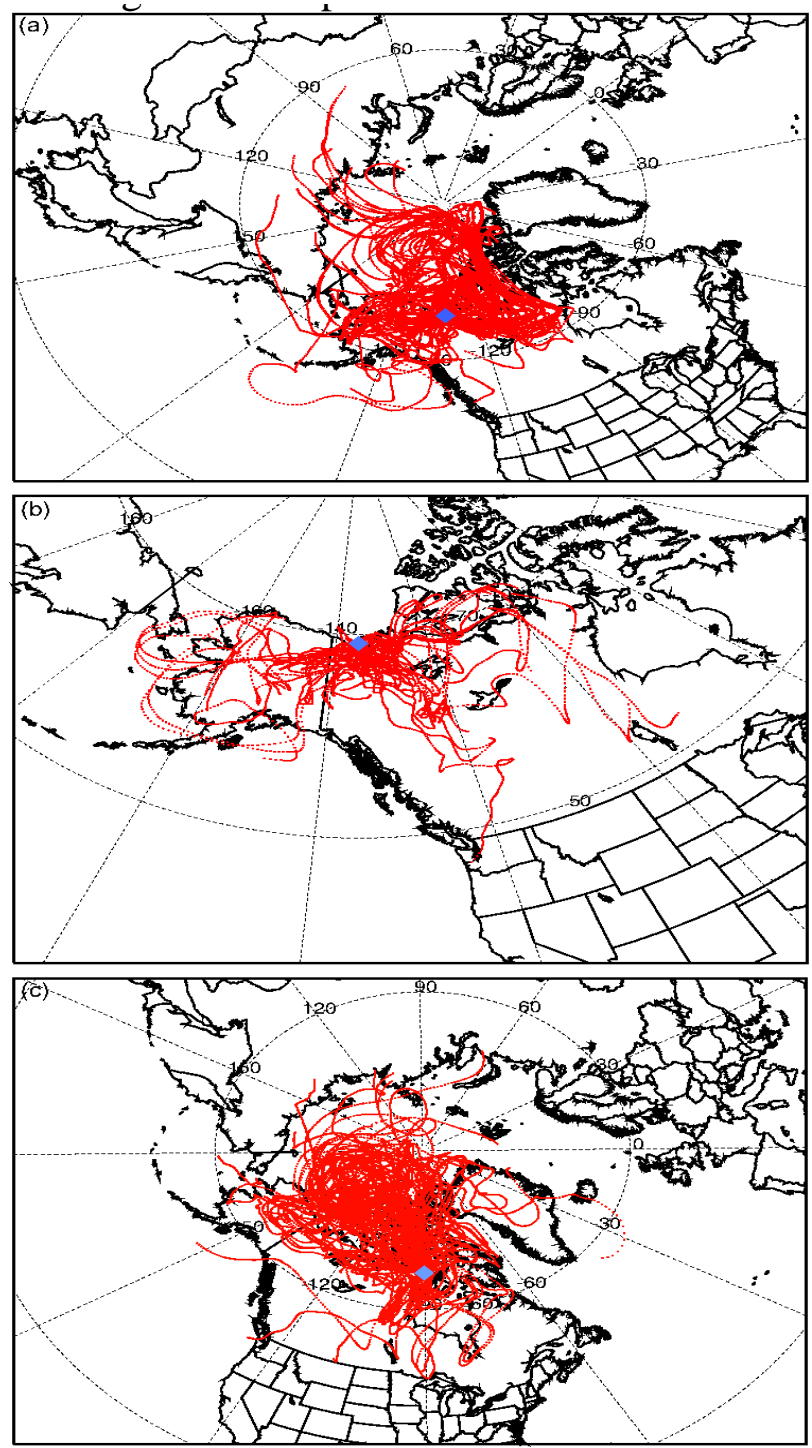

Fig. 13. (a) Back trajectories from Inuvik for the fall of 2008, the period corresponding to a strong boreal biomass-burning source. (b) For spring of 2009 for Inuvik corresponding to a strong crop and grass burning source. (c) Walker Lake in the fall of 2008, the period corresponding to the peak in crop and grass burning source impact.

large cluster of fires in late October associated with fall crop burning in the mid-west of the US and Canada, analogous to that just discussed for the spring of 2009 (see Fig. 14). Also analogous to the spring season, back trajectories for this site (Fig. 13c) show significant transport from this area to the Walker Lake site, suggesting that North American fire emissions can have, at least occasionally, some impact on LAA deposition in the Canadian Arctic.

The last profile to discuss is that from the site (21) on Little Cornwallis Island. This profile is shown in Fig. 10c and was one of the few sites to show pollution as the dominant

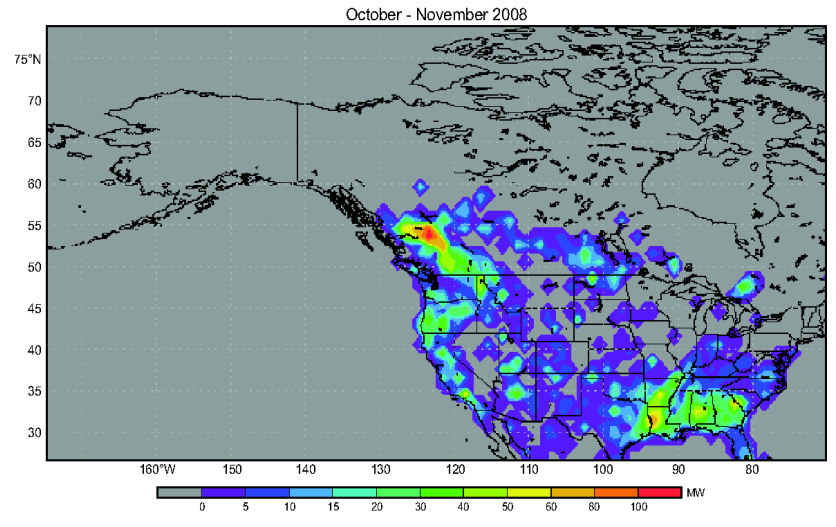

Fig. 14. Location of biomass fires in west-central North America based on the MODIS Fire Mapper (Giovanni program) for OctoberNovember of 2008. The Peace River agricultural area is situated at the maximum power location. The resolution of the fire radiative power field is $1^{\circ} \times 1^{\circ}$.

source at any depth. This dominance occurs at a depth of $4.5 \mathrm{~cm}$ and corresponds (see Fig. 11) to deposition during roughly early March. However, back trajectories for April as compared to March show very little difference, and in neither case do they encompass major known pollution sources, in accord with the relatively modest LAA levels at all depths. We speculate that the variations seen in the profile are due to local variations in sources, perhaps associated with the extensive tailings from the defunct Polaris lead and zinc mine located $\sim 25 \mathrm{~km}$ to the southwest. For such a short distance, even dry deposition of aerosol resuspended to a few meters height is feasible as a source.

\section{Conclusions}

Based on the PMF analysis of sources of LAA for data sets from both 2008 and 2009, the dominant source of LAA in the arctic snow pack appears to be biomass burning, in accord with our earlier analysis (Hegg et al,2009). Several additional pieces of information are suggested by the current analysis. First, an additional biomass marker species included in the analysis (vanillin) has permitted a reasonably credible separation of the biomass source into one attributable to crop and grass burning and one to boreal biomass burning, with the former by far the more important in the 2009 data set for the Canadian Arctic. For the 2008 data set, predominantly from Eastern Siberia, this is less the case though the crop and grass burning source is still the more important. Interpretation of the spectral absorption of the LAA has permitted a tentative resolution of the LAA into a BC and non-BC component. The two species have similar source profiles, associated almost exclusively with the biomass factors. This in itself suggests that the non-BC LAA is in fact "brown carbon", a constituent widely assumed to 
be most prevalent in biomass emissions, rather than soil dust. Source contributions as a function of sampling location show considerable variance in the 2008 data set, the variance being interpretable in terms of different source locations and transport trajectories. Less geographic variance is shown in the 2009 data set from the Canadian Arctic, but the few anomalous sites are still plausibly explicable in terms of varying source strengths and transport. Finally, in both the 2008 and 2009 data sets, the depth profiles acquired permit an assessment of the seasonality of the relative source strengths. Both data sets show the biomass burning to peak in importance in the spring, in accordance with expectations from previous work. Pollution appears to be of most importance during the late fall and winter, and in Greenland during the summer, but rarely dominates the source contribution to snow LAA.

\section{Supplement related to this article is available online at: http://www.atmos-chem-phys.net/10/10923/2010/ acp-10-10923-2010-supplement.pdf.}

Acknowledgements. We thank Sergei Zimov, Galina Zimov, and Vladimir Radionov for providing snowfall and snow depth data at Siberian sites, and Konrad Steffen and coworkers for the snow accumulation time series at Dye-2 in Greenland. Richard Brandt provided analyses of the Dye-2 time series. James Morison, Michael Steele, and Konrad Steffen collected some of the snow samples used in this study. We thank Tim Larson for many useful conversations and comments on the manuscript and Ron Sletten for running the ICP analysis. We thank one anonymous reviewer and R. Subramanian for useful comments during the review process. Back trajectories used in this study were calculated with HYSPLIT-IV (HYbrid Single-Particle Lagrangian Integrated Trajectory) Model, 1997. Web address: http://www.arl.noaa.gov/ready/hysplit4.html, NOAA Air Resources Laboratory, Silver Spring, MD. The research was supported by the Clean Air Task Force, the Oak Foundation, and NSF Grant ARC-06-12636.

Edited by: N. M. Donahue

\section{References}

Alfaro, S. C., Lafon, S., Rajot, J. L., Formenti, P., Gaudichet, A., and Maille, M.: Iron oxides and light absorption by pure desert dust: an experimental study, J. Geophys. Res., 109, D08208, doi:1029/2003JD004374, 2004.

Burkhart, J. F., Bales, R. C., McConnell, J. R., Hutterli, M. A., and Frey, M.: Geographic variability of nitrate deposition and preservation over the Greenland Ice Sheet, J. Geophys. Res., 114, D06301, doi:10.1029/2008JD010600, 2009.

Chen, M., Diehl, T., Dubovik, O., Eck, T. F., Holben, B. N., Sinyuk, A., and Streets, D. G.: Light absorption by pollution, dust, and biomass burning aerosols: global model study and evaluation with AERONET measurements, Ann. Geophys., 27, 3439-3464, doi:10.5194/angeo-27-3439-2009, 2009.

Chylek, P., Johnson, B., and Wu, H.: Black carbon concentration in a Greenland Dye-3 ice core, Geophys. Res. Lett., 19, 1951-1953, 1992.
Clarke, A. D. and Noone, K. J.: Soot in the Arctic snowpack: A cause for perturbations in radiative transfer, Atmos. Environ., 19, 2045-2053, 1985.

Doherty, S. J, Warren, S. G., Grenfell, T. C., Brandt, R. E., and Clarke, A. D.: Light-absorbing impurities in Arctic snow, Atmos. Chem. Phys. Discuss, 18807-18878, doi:10.5194/acpd-1018807-2010, 2010.

Eleftheriadis, K., Vratolis, S., and Nyeki, S.: Aerosol black carbon in the European Arctic: Measurements at Zeppelin station, Ny-Alesund, Svalbard from 1998-2007, Geophys. Res. Lett., 36, L02809, doi:10.1029/2008GL035741, 2009.

Favez, O., Alfaro, S. C., Sciare, J., Cachier, H., and Abdelwahab, M. M.: Ambient measurements of light-absorption by agricultural waste burning organic aerosols, Aerosol Sci., 40, 613-620, 2009a.

Favez, O., Cachier, H., Sciare, J., Sarda-Esteve, R., and Martinon, L.: Evidence for a significant contribution of wood burning aerosols to PM2.5 during winter season in Paris, France, Atmos. Environ., 43, 3640-3644, 2009b.

Flanner, M. G., Zender, C. S., Randerson, J. T., and Rasch, P. J.: Present-day climate forcing and response from black carbon in snow, J. Geophys. Res., 112, D11202, doi:1029/2006JD008003, 2007.

Generoso, S., Bey, I., Attie, J.-L., and Breon, F.-M.: A satelliteand model-based assessment of the 2003 Russian fires: impact on the Arctic region, J. Geophys. Res., 112, D15302, doi:10.1029/2006JD008344, 2007.

Grannas, A. M., Shepson, P. B., and Filley, T. R.: Photochemistry and nature of organic matter in Arctic and Antarctic snow, Global Biogeochem. Cy., 18, GB1006, doi:10/1029/2003GB002133, 2004.

Grenfell, T. C., Doherty, S. J., Clarke, A. D., and Warren, S. G.: Light absorption from particulate impurities in snow and ice determined by spectrophotometric analysis of filters, Appl. Opt., in review, 2010.

Grenfell, T. C., Light, B., and Sturm, M.: Spatial distribution and radiative effects of soot in the snow and sea ice during the SHEBA experiment, J. Geophys. Res., 107, 8032, doi:10.1029/2000JC000414, 2002.

Hagler, G. S. W., Bergin, M. H., Smith, E. A., and Dibb, J. E.: A summer time series of particulate carbon in the air and snow at Summit, Greenland, J. Geophys. Res., 112, D21309, doi:10.1029/2007JD008993, 2007.

Hansen, J. and Nazarenko, L.: Soot climate forcing via snow and ice albedos, Proc. Natl. Acad. Sci. (USA), 101, 423-428, 2004.

Hays, M. D., Fine, P. M., Geron, C. D, Kleeman, M. J., and Gullet, B. K.: Open burning of agricultural biomass: physical and chemical properties of particle-phase emissions, Atmos. Environ., 39, 6747-6764, 2005.

Hegg, D. A., Warren, S. G., Grenfell, T. C., Doherty, S. J., Larson, T. V., and Clarke, A. D.: Source attribution of black carbon in arctic snow, Environ. Sci. Technol., 43, 4016-4021, 2009.

Hennigan, C. J., Sullivan, A. P., Collett Jr., J. L. and Robinson, A. L.: Levoglucosan stability in biomass burning particles exposed to hydroxyl radicals, Geophys. Res. Lett., 37, L09806, doi:10.1029/2010GL043088, 2010.

Henry, R. C., Park, E. S., and Spiegelman, C. H.: Comparing a new algorithm with classic methods for estimating the number of factors, Chemom. Intell. Lab. Syst., 48, 91-97, 1999. 
Hobbs, P. V. and Rangno, A. L. Microstructures of low and middlelevel clouds over the Beaufort Sea, Q. J. Roy. Meteorol. Soc., 124, 2035-2071, 1998.

Hoffmann, D., Tilgner, A., Inuma, Y., and Herrmann, H.: Atmospheric stability of levoglucosan: a detailed laboratory and modeling study, Environ. Sci. Technol., 44, 694-699, 2010.

Kirchstetter, T. W., Novakov, T., and Hobbs, P. V.: Evidence that the spectral dependence of light absorption by aerosols is affected by organic carbon, J. Geophys. Res., 109, D21208, doi:10.1029/2004JD004999, 2004.

Liston, G. E. and Sturm, M.: The role of winter sublimation in the Arctic moisture budget, Nordic Hydrol., 35, 325-334, 2004.

Lukács, H., Gelencsér, A., Hammer, S., Puxbaum, H., Pio, C., Legrand, M., Kasper-Giebl, A., Handler, M., Limbeck, A., Simpson, D., and Preunkert, S.: Seasonal trends and possible sources of brown carbon based on 2-year aerosol measurements at six sites in Europe, J. Geophys. Res., 112, D23S18, doi:10.1029/2006JD008151, 2007.

Luo, Y., Xu, K.-M., Morrison, H., McFarquhar, G., Wang, Z., and Zhang, G. Multi-layer arctic mixed-phase clouds simulated by a cloud-resolving model: Comparison with ARM observations and sensitivity experiments, J. Geophys. Res., 113, D12208, doi:10.1029/2007JD009563, 2008.

Mahowald, N. M., Engelstaedter, S., Luo, C., Sealy, A., Artaxo, P., Benitez-Nelson, C., Bonnet, S., Chen, Y., Chuang, P. Y., Cohen, D. D., Dulac, F., Herut, B., Johansen, A. M., Kubilay, N., Losno, R., Maenhaut, W., Paytan, A., Prospero, J. M., Shank, L. M., and Siefert, R. L.: Atmospheric iron deposition: global distribution, variability, and human perturbations, Rev. Mar. Sci., 1, 245-278, 2009.

Masclet, P., Hoyau, V., Jaffrezo, J., and Cachier, H.: Polycyclic aromatic hydrocarbon deposition on the ice sheet of Greenland. Part 1: superficial snow, Atmos. Environ., 34, 3195-3207, 2000.

McConnell, J. R., Edwards, R., Kok, G. L., Flanner, M. G., Zender, C. S., Saltzman, E. S., Banta, J. R., Pasteris, D. R., Carter, M. M., and Kahl, J. D. W.: 20th-Century industrial black carbon emissions altered arctic climate forcing, Science, 317, 1381-1384, 2007.

Mochida, M., Kawamura, K., Fu, P., and Takemura, T.: Seasonal variation of levoglucosan in aerosols over the North pacific and its assessment as a biomass tracer, Atmos. Environ., 44, 35113518, 2010.

Moosmuller, H., Chakrabarty, R. K., and Arnott, W. P.: Aerosol light absorption and its measurement: a review, J. Quant. Spectrosc. Radiat. Transfer, 110, 844-878, 2009.

Morrison, H., Curry, J. A., Shupe, M. D., and Zuidema, P. A new double-moment microphysics parameterization for application in cloud and climate models. Part II: Single-column modeling of Arctic clouds, J. Atmos. Sci., 62, 1678-1693, 2005.

Norris, G., Vedantham, R., Wade, K., Brown, S., Prouty, J., and Foley, C.: EPA Positive Matrix Factorization (PMF) 3.0 Fundamentals \& User Guide. EPA report 600/R-08/108, available online at: www.epa.gov, July, 2008.

Oros, D. R. and Simoneit, B. R. T.: Identification and emission factors of molecular tracers in organic aerosols from biomass burning. Part 1. Temperate climate conifers, Appl. Geochem., 16, 1513-1544, 2001a.

Oros, D. R. and Simoneit, B. R. T.: Identification and emission factors of molecular tracers in organic aerosols from biomass burn- ing. Part 2. Deciduous trees, Appl. Geochem, 16, 1545-1565, 2001b.

Oros, D. R., Radzi bin Abas, M., Omar, N. Y. M. J., Rahman, N. A., and Simoneit, B. R. T.: Identification and emission factors of molecular tracers in organic aerosols from biomass burning. Part 3. Grasses, Appl. Geochem., 21, 919-940, 2006.

Paatero, P. and Tapper, U.: Positive matrix factorization: a nonnegative factor model with optimal utilization of error estimates of data values, Environmetrics, 5, 111-126, 1994.

Perovich, D. K., Grenfell, T. C., Light B., Elder, B. C., Harbeck, J., Polashenski, C., Tucker, W. B. III, and Stelmach, C.: Transpolar observations of morphological properties of Arctic sea ice, J. Geophys. Res., 114, C00A04, doi:10.1029/2008JC004892, 2009.

Polissar, A., Hopke, P., Malm, W., and Sisler, J.: Atmospheric aerosol over Alaska 1. Elemental composition and sources, J. Geophys. Res., 103, 19045-19057,1998.

Quinn, P. K., Shaw, G., Andrews, E., Dutton, E. G., Ruoho-Airola, T., and Gong, S. L.: Arctic haze: current trends and knowledge gaps, Tellus, 59B, 99-114, 2007.

Rahn, K. A., Lewis, N. F., Lowenthal., D. H, and Smith, D. L.: Noril'sk only a minor contributor to Arctic haze, Nature, 306, 459-461, 1983.

Ramanathan, V. and Carmichael, G.: Global and regional climate change due to black carbon, Nature Geoscience, 1, 221-227, 2008.

Sandradewi, J., Prevot, A. S. H., Szidat, S., Perron, N., Alfarra, M. R., Lanz, V. A., Weingartner, E., and Baltensperger, U.: Using aerosol light absorption measurements for quantitative determination of wood burning and traffic emission contributions to particulate matter, Environ. Sci. Technol., 42, 3316-3323, 2008.

Sharma, S., Andrews, E., Barrie, L., Ogren, J., and Lavoue, D.: Variations and sources of equivalent black carbon in the high Arctic revealed by long-term observations at Alert and Barrow: 1989-2003, J. Geophys. Res., 111, D14208, doi:10.1029/2005JD006581, 2006.

Shindell, D. and Faluvegi, G.: Climate response to regional radiative forcing during the twentieth century, Nature Geosci., 2, doi:10.1038/NGEO473, 294-300, 2009.

Simoneit, B. R. T.: Biomass burning a review of organic tracers for smoke from incomplete combustion, Appl. Geochem., 17, 129$162,2002$.

Steffen, K., Box, J. E., and Abdalati, W.: Greenland Climate Network: GC-Net, in: Glaciers, Ice Sheets and Volcanoes, edited by: Colbeck, S. C., CRREL Special Report 96-27, US Army Cold Regions Research and Engineering laboratory, Hanover, NH, USA, 98-103, 1996.

Stohl, A.: Characteristics of atmospheric transport into the arctic troposphere, J. Geophys. Res., 111, D11306, doi:10.1029/2005JD006888, 2006.

Stohl, A., Andrews, E., Burkhart, J. F., Forster, C., Herber, A., Hoch, S. W., Kowal, D., Lunder, C., Mefford, T., Ogren, J. A., Sharma, S., Spichtinger, N., Stebel, K., Stone, R., Ström, J., Tørseth, K., Wehrli, C., and Yttri, K. E.: Pan-arctic enhancements of light absorbing aerosolconcentrations due to North American boreal forest fires during summer 2004, J. Geophys. Res., 111, D22214, doi:10.1029/2006JD007216, 2006.

Sun, H., Biedermann, L., and Bond, T. C. Color of brown carbon: a model for ultraviolet and visible light absorption 
by organic carbon aerosol, Geophys. Res. Lett., 34, L17813, doi:10.1029/2007GL029797, 2007.

Toledano, C., Cachorro, V. E., de Frutos, A. M., Torres, B., Berjon, A., Sorribas, M., and Stone, R. S.: Airmass classification and analysis of aerosol types at El Arenosillo (Spain), J. Appl. Meteor. Climat., 48, 962-981, 2009.

Treffeisen, R., Herber, A., Strom, J., Shiobara, M., Yamanouchi, T., Yamagata, S., Holmen, K., Kriews, M., and Schrems, O.: Interpretation of Arctic aerosol properties using cluster analysis applied to observations from the Svalbard area, Tellus, 56B, 457476, 2004.

Ulbrich, I. M., Canagaratna, M. R., Zhang, Q., Worsnop, D. R. and Jimenez, J. L. Interpretation of organic components from Positive Matrix Factorization of aerosol mass spectrometer data, Atmos. Chem. Phys., 9, 2891-2918, 2009.
Warneke, C., Bahreini, R., Brioude, J., Brock, C. A., de Gouw, J. A., Fahey, D. W., Froyd, K. D., Holloway, J. S., Middlebrook, A., Miller, L., Montzka, S., Murphy, D. M., Peischl, J., Ryerson, T. B., Schwartz, J. P., Spockman, J. R., and Veres, P.: Biomass burning in Siberia and Kazakhstan as an important source for haze over the Alaskan Arctic in April, 2008, Geophys. Res. Lett., 36, L02813, doi:10.1029/2008GL036194, 2009.

Xie, Y.-L., Hopke, P. K., Paatero, P., Barrie, L. A., and Li, S.-M.: Identification of source nature and seasonal variations of Arctic aerosol by positive matrix factorization, J. Atmos. Sci., 56, 249260, 1999. 